SYSTEMATIC REVIEW

\title{
Review of Measures of Worksite Environmental and Policy Supports for Physical Activity and Healthy Eating
}

\author{
J. Aaron Hipp, PhD; Dominic N. Reeds, MD; Margaret A. van Bakergem, MPH; \\ Christine M. Marx, MA; Ross C. Brownson, PhD; Surya C. Pamulapati, MPH; \\ Christine M. Hoehner, PhD
}

\begin{abstract}
Suggested citation for this article: Hipp JA, Reeds DN, van Bakergem MA, Marx CM, Brownson RC, Pamulapati SC, et al. Review of Measures of Worksite Environmental and Policy Supports for Physical Activity and Healthy Eating. Prev Chronic Dis 2015;12:140410. DOI: http://dx.doi.org/10.5888/ pcd12.140410.
\end{abstract}

\section{PEER REVIEWED}

\section{Abstract}

\section{Introduction}

Obesity prevention strategies are needed that target multiple settings, including the worksite. The objective of this study was to assess the state of science concerning available measures of worksite environmental and policy supports for physical activity (PA) and healthy eating (HE).

\section{Methods}

We searched multiple databases for instruments used to assess worksite environments and policies. Two commonly cited instruments developed by state public health departments were also included. Studies that were published from 1991 through 2013 in peer-reviewed publications and gray literature that discussed the development or use of these instruments were analyzed. Instrument administration mode and measurement properties were documented. Items were classified by general health topic, 5 domains of general worksite strategy, and 19 subdomains of worksite strategy specific to PA or HE. Characteristics of worksite measures were described including measurement properties, length, and administration mode, as well as frequencies of items by domain and subdomain.

\section{Results}

Seventeen instruments met inclusion criteria ( 9 employee surveys, 5 manager surveys, 1 observational assessment, and 2 studies that used multiple administration modes). Fourteen instruments included reliability testing. More items were related to PA than HE. Most instruments $(\mathrm{n}=10)$ lacked items in the internal social environment domain. The most common PA subdomains were exercise facilities and lockers/showers; the most common HE subdomain was healthy options/vending.

\section{Conclusion}

This review highlights gaps in measurement of the worksite social environment. The findings provide a useful resource for researchers and practitioners and should inform future instrument development.

\section{Introduction}

Overweight and obesity are major health challenges because of their high prevalence, causal relationship with serious medical complications, and economic impact (1). The risk of developing many diseases, including type 2 diabetes, increases linearly with body mass index (2-6). Obesity prevention strategies are needed that target multiple levels of the ecologic framework across multiple settings, including the worksite. Using the worksite as a venue for health promotion is promising, because most adults spend approximately half of their waking day in their work environment (6). Research suggests that environmental and policy strategies for addressing energy balance (ie, caloric intake and energy expenditure through physical activity [PA]) in the workplace are effective (7-9). Use of worksite programs to improve employee health has been recommended by the American Cancer Society, the Centers for Disease Control and Prevention, and multiple state govern- 
ments. Occupational settings take advantage of a captive population and may have existing facilities, social support, convenience, and communication mechanisms in place (10).

Targeting work environments for energy balance includes using policies, programs, and organizational practices to influence behavior. Example work environments include onsite facilities such as gymnasiums, lockers, showers, accessible stairways, and healthy vending options. Policies and programs include subsidized external gymnasium memberships; incentives to bicycle, walk, or use public transportation for the commute to and from work; and group services such as onsite yoga and health fairs (11). By facilitating access to inexpensive healthy food, exercise facilities, and a culture accepting of nonsedentary work breaks, worksites can become sites for health promotion via a healthy energy balance (6). Although tools are available for assessing worksite environments and policies in place for PA and healthy eating (HE), no review has documented the content and measurement properties of these tools. Such a review of worksite energy measurement tools could serve as a guide for researchers, practitioners, and worksites in selecting among existing tools and understanding methodologic gaps to guide potential development of new instruments. The purpose of this review was to identify and assess the state of science concerning available measurement instruments related to worksite environment and policy supports for workplace energy balance.

\section{Methods}

The literature review was completed in May 2014, using PubMed, OVID, MedLine, Web of Science, and the Registry of Measures from the National Collaborative on Childhood Obesity. We also searched sources of gray literature, including Google Scholar and state health departments. Search terms were key words for worksites, energy balance, and measurement: (work OR worksite OR workplace OR employer OR job) AND (physical activity OR physical fitness OR diet OR exercise OR obesity OR active commuting) AND (evaluation OR monitor* OR survey OR questionnaire OR data collection). Titles of applicable results were screened for their relevance to the assessment of worksite environment and policy measurement, tool development, and worksite interventions targeting PA and $\mathrm{HE}$.

The search was restricted to articles published in English from 1991 through 2013. Abstracts were scanned and accepted if related to 1 or more of the following criteria designed to capture the presence or absence of worksite supports and policies associated with employee PA and HE (eg, presence of an onsite gymnasium, incentives to use public transportation to and from work): 1) studies describing measurement properties of a specific instrument, 2) descriptive studies of environmental and policy supports among a sample of employees or worksites, and 3) cross-sectional or intervention studies that used a specified instrument or explicitly stated the items used to systematically assess worksite environment and policies and their potential associations with PA and HE. Full-text articles were scanned when the information from abstracts was insufficient to make a conclusion about inclusion. Abstracts were excluded if they focused solely on the development or implementation or both of worksite health promotion programs and, thus, were not related to measuring current supports and policies. Moreover, abstracts were rejected if they did not emphasize policy or environmental supports in a nonhome-based worksite. Finally, full-text articles and their reference lists were scanned for references that cited the development of a specific worksite tool, survey, or checklist on policies and environmental supports related to PA and HE. The instruments used among articles that met inclusion criteria were abstracted. Each instrument was categorized on the basis of 1 of 4 administration options: employee or self-report, manager report, observational, or multiple modes. Measurement properties, including reliability and validity, were documented.

The final component of the review involved classifying each unique instrument item into an item inventory. Items were first classified by the general health topic they addressed: PA, HE, or both (healthy eating and physical activity [HEPA]). Next, items were classified by the general worksite strategy being assessed, referred to as the primary domain. These strategies are based on the ecological model, the Guide to Community Preventive Services, and research by Kahn et al $(12,13)$ and include promotions and programs (eg, informational media), organizational policies and practices (eg, incentives), internal physical environment (eg, access to healthy food and PA options), internal social environment (eg, role models), and external environment (eg, worksite neighborhood options for HE and PA). Primary domains were further disaggregated into subdomains by using constant comparison to classify the PA (19 subdomains) and HE (19 subdomains) strategies (Table 1). Interrater agreement for classifying the instrument items was $85 \%$ among 3 raters.

\section{Results}

Seventeen worksite instruments were identified that included items about worksite environment and policies related to PA, HE, or both and met inclusion criteria. The administration modes of the 17 instruments varied $(\mathrm{n}=9$ self-report; $\mathrm{n}=5$ manager report, $\mathrm{n}=$ 1 observational; and $n=2$ using multiple modes) as did the total number of HE and PA items per instrument (range, 10-226) (Table 2). More items were related to PA than to HE. Nine instruments included both PA and HE items, 7 instruments had only PA items, and only 1 included solely HE items related to worksite environment and policy supports. Of the 17 instruments, 14 reported

The opinions expressed by authors contributing to this journal do not necessarily reflect the opinions of the U.S. Department of Health and Human Services, the Public Health Service, the Centers for Disease Control and Prevention, or the authors' affiliated institutions. 
reliability, of which 8 reported generally high interrater results (Table 2). Five instruments reported various validity measures including content, face, predictive, and construct validity results. Health promotion experts provided substantial guidance in development of the instruments, and significant correlations were found for workplace environmental sections within the instruments. The item inventory indicated that the most common health topic was PA (PA and HEPA) (64\% of all items [n=669]). HE (HE and HEPA) consisted of 369 items, or $36 \%$.

\section{Physical activity}

Two instruments, the Environmental Assessment Tool (EAT) (29) and the Checklist of Health Promotion Environments at Worksites (CHEW) (34), had the highest number of PA items (151 and 107, respectively) and used multiple modes of administration. Of the 17 instruments, only 1, Working Well Trial (WWT) (33), did not contain items related to PA. Of the surveys with PA items, most (14 of 16) included at least 1 item related to the external environment relevant for PA (Figure 1). The domain that was represented by the fewest number of instruments was the internal social environment, with only 7 total instruments containing at least 1 PA item for that domain. In terms of subdomains, only 1 instrument contained an item related to community partnerships, workplace challenges, or office connectivity, whereas 12 covered the subdomains counseling/classes/education, access to PA equipment, and lockers and showers.

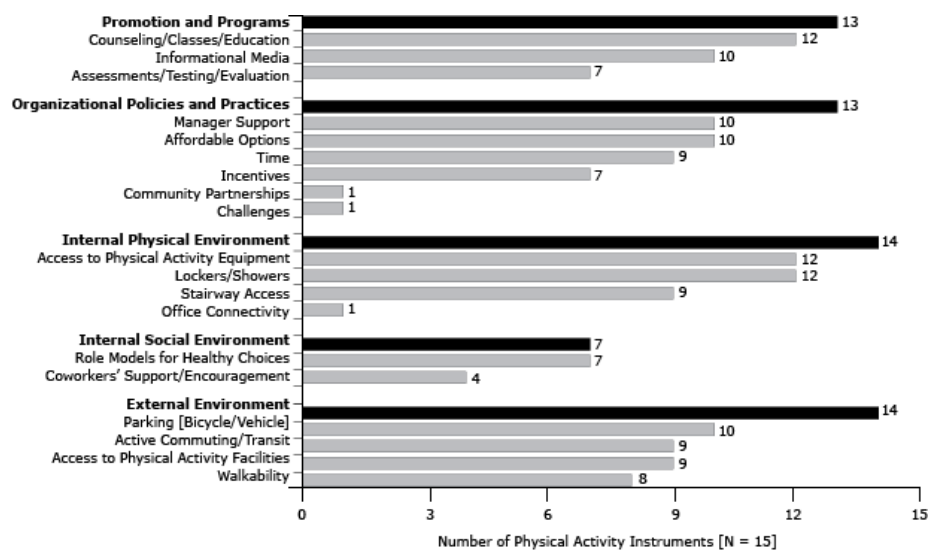

Figure 1. Number of instruments containing at least 1 item from each physical activity domain and subdomain $(\mathrm{N}=15)$, review of measures of worksite environmental and policy supports for physical activity and healthy eating, United States, 1991-2013.

Specific results for each instrument were also explored. Of the 19 subdomains for PA-related items, the California Worksite Assess- ment Checklist (CA) instrument included items covering the most subdomains (16 of 19 subdomains). The Workplace Walkability Audit Tool (WWAT) instrument covered the fewest subdomains (1 of 17 subdomains).

\section{Healthy eating}

Of the 5 primary domains, 3 (promotion and programs, organizational policies and practices, and internal physical environment) had the greatest coverage, with 9 of the 10 healthy eating instruments containing at least 1 item for each respective primary domain (Figure 2). Similar to the findings for PA domain coverage, the primary domain with the least coverage was the internal social environment; 5 of the $10 \mathrm{HE}$ instruments covered that topic. Additionally, a noticeable gap is indicated through the external environment primary domain; only 6 instruments covered HE items related to the external food environment of worksites. The California Worksite Assessment Checklist (CA) instrument (21) spanned the greatest number of HE subdomains (15 of 19 subdomains). The HE instrument with the least coverage, Workplace Nutrition and Exercise Climate Scale (WNECS) (25), included items across 5 of the 19 subdomains.

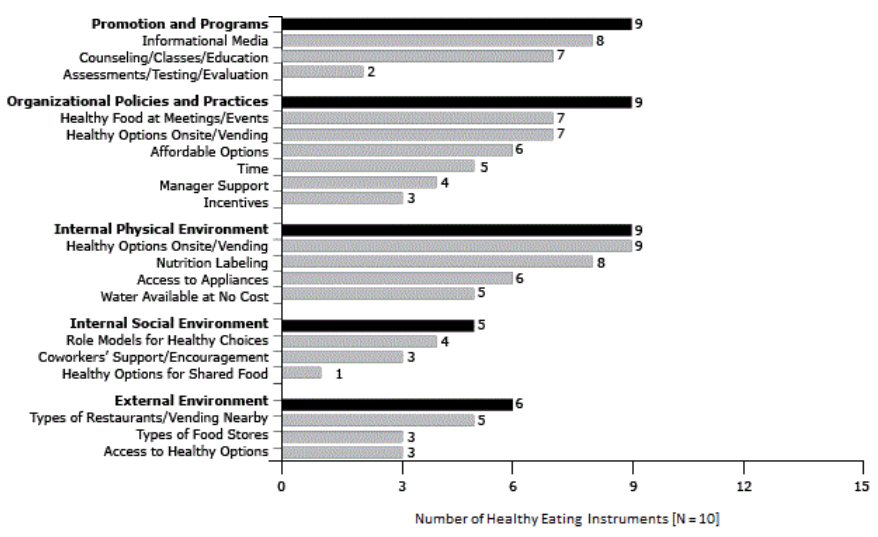

Figure 2. Number of instruments containing at least 1 item from each healthy eating domain and subdomain $(N=10)$, review of measures of worksite environmental and policy supports for physical activity and healthy eating, United States, 1991-2013.

\section{Discussion}

As a venue for delivering $\mathrm{HE}$ and PA efforts, worksites provide a channel for reaching the large segment of the population that is employed (147 million as of November 2014, according to the US Bureau of Labor Statistics) (6,10). Moreover, measuring environmental and policy supports for PA and HE in the workplace is an

The opinions expressed by authors contributing to this journal do not necessarily reflect the opinions of the U.S. Department of Health and Human Services, the Public Health Service, the Centers for Disease Control and Prevention, or the authors' affiliated institutions. 
important component in assessing and addressing the factors related to overweight and obesity (14). This review of worksite measures identified various data collection instruments and highlights several matters that require further consideration and attention for future research.

The results of the item inventory highlight both extensive and deficient domain coverage for both PA- and HE-related items. Overall, the primary domains of promotion and programs, organizational policies and practices, and internal physical environment had the greatest coverage among HE and PA items. The primary domain of internal social environment had few items for either HE or PA. We also found several administration modes used, most instruments being self-report. Only 1 instrument was observational (WWAT), although several used multiple methods. With 14 of the 17 instruments relying on either employee or manager self-report, the state of worksite PA and HE measurement is susceptible to respondent and social desirability bias. Regarding measurement properties, most instruments (14 of 17) reported high reliability results, mostly interrater measures. Validity was assessed for 5 instruments, with emphasis on content validation.

There was variety in the content gaps of the measures reviewed. Overall, there were few documented measures about HE in and around the workplace. Most HE measures focused on onsite cafeteria and vending options but neglected external environments (eg, healthy options within a 10-minute walk), organizational policies (eg, healthy snacks at meetings and events), and the social environment. The promotion and programs domain contains 8 measures with items related to informational media and 7 with classes or education (both subdomains); however, only 2 of 10 instruments included any items on assessments, testing, evaluation, and HE. Provided that a full-time employee spends at least 8 hours per day at the worksite - therefore, at least 1 meal is consumed at or near work during most working days - the gaps in HE measures is an important finding that deserves further attention. Exploring the diverse aspects of food environments near workplaces, rather than solely assessing onsite cafeteria and vending options, would be beneficial.

Of the 5 domains, internal social environment was included in the fewest HE- and PA-related instruments. Social environments, including role models, champions, and support, are highly associated with PA and obesity $(15,16)$. Among the subdomains, specialized instruments (ie, Office Environment and Sitting Scale [20], Kaczynski et al [22], and the WWAT [30]) had minimal, if any, coverage. Also, despite including more than 100 unique items, CHEW had minimal coverage for the HE subdomains (only 9 of 19 subdomains covered) (Appendix).
Performing this review did have challenges and limitations. Forcing instrument items into domains and especially subdomains presented some difficulties in operationalizing the specific items. Items could also fit into more than 1 subdomain. The process of developing the subdomains was iterative; new items forced ever greater specificity in the naming and operationalization of the 38 subdomains. However, the specificity of selected subdomains such as walkability, which can include land use mix, aesthetics, and sidewalks, compared with stairway access, which only refers to the presence of stairs - still varies greatly. We were systematic and prescriptive in our literature search for worksite measures, but this may not be an exhaustive list of worksite instruments, especially those present in the gray literature. Finally, Carnethon and colleagues (17) suggest that efforts moving forward must not only focus on PA but also reduce sedentary behaviors at worksites, and this can be accomplished via policies and designs. Future worksite measurements must do a better job of including sedentary behaviors in their instruments.

This review provides a concise guide for employers to existing worksite measures on PA and HE, both for selecting appropriate assessment instruments for the worksite and as a means to introduce new policies and programs to support healthy workers. For example, employers can administer health risk appraisals in combination with organizational health promotion checklists that have been developed. This approach would provide information to the employee and employer where there may be overlap or gaps between worksite supports and health risks and benefits. Social and physical environments in and around the workplace should be designed to be conducive to recommended healthy behaviors (18). In addition, optimal environmental modifications should promote healthy behaviors while simultaneously minimizing the physical, organizational, and occupational risk in the work environment.

\section{Acknowledgments}

This study was supported by the National Cancer Institute's Centers for Transdisciplinary Research on Energetics and Cancer (TREC 2011-2016; no. U54 CA155496) and National Institutes of Health (NIH)/National Institute of Diabetes and Digestive and Kidney Diseases (NIDDK) no. P30DK092950 and the Washington University Center for Diabetes Translation Research (WUCDTR). This article's contents are solely the responsibility of the authors and do not necessarily represent the official view of the WU-CDTR, NIDDK, or NIH. We acknowledge the support of the Washington University Institute for Public Health for cosponsoring, with the WU-CDTR, the Next Steps in Public Health event that led to the development of this article. We thank Lina Cai and Calista Alaribe for their assistance with the literature review.

\footnotetext{
The opinions expressed by authors contributing to this journal do not necessarily reflect the opinions of the U.S. Department of Health and Human Services, the Public Health Service, the Centers for Disease Control and Prevention, or the authors' affiliated institutions.
} 


\section{Author Information}

Corresponding Author: J. Aaron Hipp, PhD, Brown School, Prevention Research Center, Washington University in St Louis, One Brookings Dr, Campus Box 1196, St Louis, MO 63130. Telephone: 314-935-3868. Email: ahipp@wustl.edu.

Author Affiliations: Dominic N. Reeds, Christine M. Marx, Washington University School of Medicine, St Louis, Missouri; Margaret A. van Bakergem, Vanderbilt University Medical Center, Nashville, Tennessee; Ross C. Brownson, Christine M. Hoehner, Prevention Research Center, Washington University in St Louis, St Louis, Missouri; Surya C. Pamulapati, University of Missouri, Columbia, Columbia, Missouri.

\section{References}

1. James WP. WHO recognition of the global obesity epidemic. Int J Obes 2008;32( Suppl 7):S120-6.

2. Needham BL, Epel ES, Adler NE, Kiefe C. Trajectories of change in obesity and symptoms of depression: the CARDIA study. Am J Public Health 2010;100(6):1040-6.

3. Logue J, Murray HM, Welsh P, Shepherd J, Packard C, Macfarlane $\mathrm{P}$, et al. Obesity is associated with fatal coronary heart disease independently of traditional risk factors and deprivation. Heart 2011;97(7):564-8.

4. Yang L, Hipp JA, Marx CM, Brownson RC. Occupational sitting and weight status in a diverse sample of employees in Midwest metropolitan cities, 2012-2013. Prev Chronic Dis 2014;11:140286.

5. Kitahara CM, Flint AJ, Berrington de Gonzalez A, Bernstein L, Brotzman M, MacInnis RJ, et al. Association between class III obesity (BMI of $40-59 \mathrm{~kg} / \mathrm{m} 2$ ) and mortality: a pooled analysis of 20 prospective studies. PLoS Med 2014; 11(7):e1001673.

6. Gorman E, Ashe MC, Dunstan DW, Hanson HM, Madden K, Winkler EAH, et al. Does an 'activity-permissive' workplace change office workers' sitting and activity time? PLoS ONE 2013;8(10):e76723.

7. Choi B, Schnall P, Dobson M, Israel L, Landsbergis P, Galassetti P, et al. Exploring occupational and behavioral risk factors for obesity in firefighters: a theoretical framework and study design. Saf Health Work 2011;2(4):301-12.

8. Faghri PD, Kotejoshyer R, Cherniack M, Reeves D, Punnett L. Assessment of a worksite health promotion readiness checklist. J Occup Environ Med 2010;52(9):893-9.
9. Division of Nutrition. Physical Activity, and Obesity. Atlanta (GA): Centers for Disease Control and Prevention; 2009. http:/ /www.cdc.gov/nccdphp/dnpa/index.htm. Accessed April 14, 2009.

10. Engbers LH, van Poppel MN, Chin A Paw MJ, van Mechelen W. Worksite health promotion programs with environmental changes: a systematic review. Am J Prev Med 2005; 29(1):61-70.

11. Dodson EA, Lovegreen SL, Elliott MB, Haire-Joshu D, Brownson RC. Worksite policies and environments supporting physical activity in midwestern communities. Am J Health Promot 2008;23(1):51-5.

12. Sallis JF, Cervero RB, Ascher W, Henderson KA, Kraft MK, Kerr J. An ecological approach to creating active living communities. Annu Rev Public Health 2006;27:297-322.

13. Kahn EB, Ramsey LT, Brownson RC, Heath GW, Howze EH, Powell KE, et al. The effectiveness of interventions to increase physical activity. A systematic review. Am J Prev Med 2002; 22(4, Suppl):73-107.

14. Anderson LM, Quinn TA, Glanz K, Ramirez G, Kahwati LC, Johnson DB, et al. The effectiveness of worksite nutrition and physical activity interventions for controlling employee overweight and obesity: a systematic review. Am J Prev Med 2009;37(4):340-57.

15. Christakis NA, Fowler JH. The spread of obesity in a large social network over 32 years. N Engl J Med 2007; 357(4):370-9.

16. McNeill LH, Kreuter MW, Subramanian SV. Social environment and physical activity: a review of concepts and evidence. Soc Sci Med 2006;63(4):1011-22.

17. Carnethon M, Whitsel LP, Franklin BA, Kris-Etherton P, Milani R, Pratt CA, et al. Worksite wellness programs for cardiovascular disease prevention: a policy statement from the American Heart Association. Circulation 2009; 120(17):1725-41.

18. Adlakha D, Hipp AJ, Marx C, Yang L, Tabak R, Dodson EA, et al. Home and workplace built environment supports for physical activity. Am J Prev Med 2015;48(1):104-7.

19. Hoehner CM, Budd EL, Marx CM, Dodson EA, Brownson RC. Development and reliability testing of the Worksite and Energy Balance Survey. J Public Health Manag Pract 2013; 19(3, Suppl 1):S105-13.

20. Duncan MJ, Rashid M, Vandelanotte C, Cutumisu N, Plotnikoff RC. Development and reliability testing of a selfreport instrument to measure the office layout as a correlate of occupational sitting. Int J Behav Nutr Phys Act 2013;10(1):16.

21. Check for health workplace environmental assessment. Sacramento (CA): California Department of Health Care Services; 2006.

The opinions expressed by authors contributing to this journal do not necessarily reflect the opinions of the U.S. Department of Health and Human Services, the Public Health Service, the Centers for Disease Control and Prevention, or the authors' affiliated institutions. 
22. Kaczynski AT, Bopp MJ, Wittman P. Association of workplace supports with active commuting. Prev Chronic Dis 2010;7(6):A127.

23. Blunt GH, Hallam JS. The Worksite Supportive Environments for Active Living Survey: development and psychometric properties. Am J Health Promot 2010;25(1):48-57.

24. Well workplace checklist. Wellness Council Wisconsin; 2005; https://www.wellnesscouncilwi.org/Pages/42/ Well_Workplace_Checklist.aspx. Accessed February 4, 2015.

25. Basen-Engquist K, Hudmon KS, Tripp M, Chamberlain R. Worksite health and safety climate: scale development and effects of a health promotion intervention. Prev Med 1998; 27(1):111-9.

26. Spittaels H, Foster C, Oppert J-M, Rutter H, Oja P, Sjöström $\mathrm{M}$, et al. Assessment of environmental correlates of physical activity: development of a European questionnaire. Int J Behav Nutr Phys Act 2009;6(1):39.

27. Kim S, Adamson KC, Balfanz DR, Brownson RC, Wiecha JL, Shepard D, et al. Development of the Community Healthy Living Index: a tool to foster healthy environments for the prevention of obesity and chronic disease. Prev Med 2010;50( Suppl 1):S80-5.

28. Shimotsu ST, French SA, Gerlach AF, Hannan PJ. Worksite environment physical activity and healthy food choices: measurement of the worksite food and physical activity environment at four metropolitan bus garages. Int J Behav Nutr Phys Act 2007;4(1):17.

29. DeJoy DM, Wilson MG, Goetzel RZ, Ozminkowski RJ, Wang $\mathrm{S}$, Baker KM, et al. Development of the Environmental Assessment Tool (EAT) to measure organizational physical and social support for worksite obesity prevention programs. J Occup Environ Med 2008;50(2):126-37.

30. Dannenberg AL, Cramer TW, Gibson CJ. Assessing the walkability of the workplace: a new audit tool. Am J Health Promot 2005;20(1):39-44.

31. Crespo NC, Sallis JF, Conway TL, Saelens BE, Frank LD. Worksite physical activity policies and environments in relation to employee physical activity. American Journal of Health Promotion 2011;25(4):264-71.

32. Plotnikoff RC, Prodaniuk TR, Fein AJ, Milton L. Development of an ecological assessment tool for a workplace physical activity program standard. Health Promot Pract 2005; 6(4):453-63.

33. Biener L, Glanz K, McLerran D, Sorensen G, Thompson B, Basen-Engquist K, et al. Impact of the Working Well Trial on the worksite smoking and nutrition environment. Health Educ Behav 1999;26(4):478-94.
34. Oldenburg B, Sallis JF, Harris D, Owen N. Checklist of Health Promotion Environments at Worksites (CHEW): development and measurement characteristics. Am J Health Promot 2002; 16(5):288-99.

35. Golaszewski T, Barr D, Pronk N. Development of assessment tools to measure organizational support for employee health. Am J Health Behav 2003;27(1):43-54.

\footnotetext{
The opinions expressed by authors contributing to this journal do not necessarily reflect the opinions of the U.S. Department of Health and Human Services, the Public Health Service, the Centers for Disease Control and Prevention, or the authors' affiliated institutions.
} 


\section{Tables}

\section{Table 1. Physical Activity and Healthy Eating Domain Details, Review of Measures of Worksite Environmental and Policy Supports for Physical Activity and Healthy Eating, United States, 1991-2013}

\begin{tabular}{|c|c|}
\hline Subdomain & Description \\
\hline \multicolumn{2}{|l|}{ Physical Activity } \\
\hline I. Promotion and programs & Key words: promote, posters, program, distribute \\
\hline Assessments/testing/evaluation & Employee fitness testing, measurements of employee PA, health screening \\
\hline Counseling/classes/education & $\begin{array}{l}\text { Informational support for participation in programs related to PA, organized PA activities } \\
\text { (classes, clubs, long-term programs), and educational informative sessions (seminars, } \\
\text { classes, meetings) that promote PA }\end{array}$ \\
\hline Informational media & $\begin{array}{l}\text { Worksite media sources or signage (posters, flyers, bulletin boards, maps) that encourage, } \\
\text { promote, or direct employees to participate in active behaviors; sharing of information }\end{array}$ \\
\hline II. Organizational policies and practices & Key words: policy, guidelines, manager, worksite requirements \\
\hline Affordable options & $\begin{array}{l}\text { Subsidies, worksite contributes financial assistance, free gymnasium access, insurance } \\
\text { discounts }\end{array}$ \\
\hline Time & Flex-time, specific policy where employees can participate in PA during work hours \\
\hline Incentives & Worksite sponsors financial, material, or other types of prizes, incentives, and gifts for PA \\
\hline Challenges & Worksite supports PA challenge (eg, steps per day) \\
\hline Manager support & $\begin{array}{l}\text { General statement about worksite, manager, or employer support or participation in PA } \\
\text { initiatives }\end{array}$ \\
\hline Community partnerships & $\begin{array}{l}\text { Employer engages with entities outside of work environment; affiliating or collaborating with } \\
\text { community organizations to improve health }\end{array}$ \\
\hline III. Internal physical environment & Key words: access, interior, facilities - anything indoors \\
\hline Access to PA equipment & Fitness centers, machines (ellipticals, treadmills), free weights, areas designated for PA \\
\hline Stairway access & Access, visible, safe; general qualities about stairs \\
\hline Lockers/showers & Access and availability; qualities about lockers/showers \\
\hline Office connectivity & Hallways, passages, route, intersect, room, workstation \\
\hline IV. Internal social environment & Key words: coworker, support, values \\
\hline Role models for healthy choices & Peer modeling, coworkers as guides and good examples, coworker PA behavior \\
\hline Coworkers' support/encouragement & Positive interaction between employee and coworkers in favor of PA or healthy activities \\
\hline $\begin{array}{l}\text { V. External physical and social } \\
\text { environment }\end{array}$ & Key words: worksite neighborhood, outdoor, access \\
\hline Walkability & $\begin{array}{l}\text { Land use mix, sidewalks/paths/trails, traffic, aesthetics, crime, safety, access to public } \\
\text { transit }\end{array}$ \\
\hline Parking (bicycle/vehicle) & $\begin{array}{l}\text { Vehicle and bicycle outdoor parking, safe areas for bicycles, carpool parking spots, parking a } \\
\text { vehicle farther away to increase walking distance to work }\end{array}$ \\
\hline Active commuting/transit & Bicycle lanes, lockers, and showers only in reference to active commuting \\
\hline Access to PA facilities & Walking distance to areas dedicated to PA, recreational facilities, parks, open space \\
\hline \multicolumn{2}{|l|}{ Healthy Eating } \\
\hline I. Promotion and programs & \\
\hline & Key words: promote, posters, program, distribute \\
\hline
\end{tabular}

Abbreviations: $\mathrm{HE}$, healthy eating; PA, Physical activity. 
(continued)

Table 1. Physical Activity and Healthy Eating Domain Details, Review of Measures of Worksite Environmental and Policy Supports for Physical Activity and Healthy Eating, United States, 1991-2013

\begin{tabular}{|c|c|}
\hline Subdomain & Description \\
\hline Assessments/testing/evaluation & Employee fitness testing, measurements of employee HE, health screening \\
\hline Counseling/classes/education & $\begin{array}{l}\text { Informational support for participation in programs related to } \mathrm{HE} \text {, organized HE activities } \\
\text { (classes, clubs, long-term programs), educational informative sessions (seminars, classes, } \\
\text { meetings) that promote HE }\end{array}$ \\
\hline Informational media & $\begin{array}{l}\text { Worksite media sources or signage (posters, flyers, bulletin boards) that encourage, } \\
\text { promote, or direct employees to participate in HE; sharing of information }\end{array}$ \\
\hline Affordable options & Cafeteria has discounts for healthy food \\
\hline Time & $\begin{array}{l}\text { Flexible lunch breaks, sufficient time to eat properly, ability to leave work to access healthy } \\
\text { food store, lunch is enforced at worksite }\end{array}$ \\
\hline Incentives & Worksite sponsors financial, material, or other types of prizes, incentives, and gifts for HE \\
\hline Healthy food at meetings/events & $\begin{array}{l}\text { Specific to catered food, worksite contracts with healthy food service, provides fruits and } \\
\text { vegetables and healthy beverages }\end{array}$ \\
\hline Manager support & $\begin{array}{l}\text { General statement about worksite, manager, or employer support or participation in HE } \\
\text { initiatives }\end{array}$ \\
\hline III. Internal physical environment & Key words: access, interior, facilities - anything indoors \\
\hline No-cost water & $\begin{array}{l}\text { Water dispensers/coolers, drinking fountains, contracts with water company, available and } \\
\text { free to employees at any time }\end{array}$ \\
\hline Nutrition labeling & Presence of nutrition labeling in cafeteria or vending machines \\
\hline Healthy options onsite/vending & $\begin{array}{l}\text { Statement that healthy and nutritious options are available or offered onsite in both } \\
\text { cafeteria and vending machines }\end{array}$ \\
\hline Access to appliances & $\begin{array}{l}\text { Worksite environment has access to refrigerator, microwave, toaster, or other appliances } \\
\text { that make it possible for employees to bring food from home or cook during work }\end{array}$ \\
\hline Coworkers' support/encouragement & Positive interaction between employee and coworkers in favor of $\mathrm{HE}$ or healthy activities \\
\hline $\begin{array}{l}\text { V. External physical and social } \\
\text { environment }\end{array}$ & Key words: neighborhood, restaurant, store, outdoor, access \\
\hline Access to healthy options & $\begin{array}{l}\text { Not referencing a specific vendor (restaurant/store), but the availability of healthy foods not } \\
\text { associated with a store/restaurant (eg, low-fat items, fruits and vegetables) }\end{array}$ \\
\hline Types of food stores & Grocery stores, farmers market; stores where employees can shop for food \\
\hline Types of restaurants/vending nearby & Fast food, convenience stores that sell food for immediate consumption \\
\hline
\end{tabular}

Abbreviations: HE, healthy eating; PA, Physical activity.

The opinions expressed by authors contributing to this journal do not necessarily reflect the opinions of the U.S. Department of Health and Human Services, the Public Health Service, the Centers for Disease Control and Prevention, or the authors' affiliated institutions. 
Table 2. Worksite Questionnaire Details, Review of Measures of Worksite Environmental and Policy Supports for Physical Activity and Healthy Eating, United States, 1991-2013

\begin{tabular}{|c|c|c|c|c|c|c|c|}
\hline Survey Name & $\begin{array}{l}\text { Administration } \\
\text { Mode }\end{array}$ & Year & $\begin{array}{c}\text { Survey Details } \\
\text { (No. of Items, } \\
\text { Time } \\
\text { Required) }\end{array}$ & $\begin{array}{c}\text { Sample (a. Sample } \\
\text { Size, b. Location, c. } \\
\text { Type of Worksite) }\end{array}$ & Reliability & Validity & $\begin{array}{l}\text { Health } \\
\text { Topic }\end{array}$ \\
\hline $\begin{array}{l}\text { California Worksite } \\
\text { Assessment } \\
\text { Checklist (CA) (21) }\end{array}$ & Self-report & 2010 & 31, NR & $\begin{array}{l}\text { a. NA } \\
\text { b. NA } \\
\text { c. NA }\end{array}$ & NR & NR & $\mathrm{PA} / \mathrm{HE}$ \\
\hline $\begin{array}{l}\text { Worksite } \\
\text { Supportive } \\
\text { Environments for } \\
\text { Active Living } \\
\text { Survey (SEALS) } \\
(23)\end{array}$ & Self-report & 2010 & $28,<30 \mathrm{~min}$ & $\begin{array}{l}\text { a. } 1,250 \text { Working } \\
\text { adults } \\
\text { b. Mid-South United } \\
\text { States } \\
\text { c. Higher education } \\
\text { campus }\end{array}$ & $\begin{array}{l}\text { Internal } \\
\text { consistency } \\
\text { Test-retest } \\
\text { Construct }\end{array}$ & $\begin{array}{l}\text { Face } \\
\text { Content } \\
\text { Discriminant }\end{array}$ & PA \\
\hline $\begin{array}{l}\text { Check for Health } \\
\text { (WI) (24) }\end{array}$ & Manager report & 2010 & $68, N R$ & $\begin{array}{l}\text { a. NA } \\
\text { b. NA } \\
\text { c. NA }\end{array}$ & NR & NR & $\mathrm{PA} / \mathrm{HE}$ \\
\hline $\begin{array}{l}\text { Workplace } \\
\text { Nutrition and } \\
\text { Exercise Climate } \\
\text { Scale (WNECS) } \\
(25)\end{array}$ & Self-report & 2010 & 119, NR & $\begin{array}{l}\text { a. } 156 \text { Full-time } \\
\text { workers } \\
\text { b. Florida } \\
\text { c. Variety }\end{array}$ & $\begin{array}{l}\text { Internal } \\
\text { consistency } \\
\text { Interrater }\end{array}$ & NR & $\mathrm{PA} / \mathrm{HE}$ \\
\hline $\begin{array}{l}\text { Community } \\
\text { Healthy Living } \\
\text { Index (CHLI) (27) }\end{array}$ & Manager report & 2008 & 75, NR & $\begin{array}{l}\text { a. Task force of } 20 \\
\text { experts } \\
\text { b. NA } \\
\text { c. NA }\end{array}$ & Interrater & NR & $\mathrm{PA} / \mathrm{HE}$ \\
\hline $\begin{array}{l}\text { Worksite } \\
\text { Environmental } \\
\text { Measure (WEM) } \\
(28)\end{array}$ & Manager report & 2007 & $105,>30 \mathrm{~min}$ & $\begin{array}{l}\text { a. } 4 \text { Bus garages } \\
\text { b. Minneapolis/St } \\
\text { Paul } \\
\text { c. Bus garage (indoor/ } \\
\text { outdoor) }\end{array}$ & Interrater & NR & $\mathrm{PA} / \mathrm{HE}$ \\
\hline $\begin{array}{l}\text { Environmental } \\
\text { Assessment Tool } \\
\text { (EAT) (29) }\end{array}$ & Multiple & 2006 & $105,>30 \mathrm{~min}$ & $\begin{array}{l}\text { a. } 12 \text { Worksites } \\
\text { b. Not reported } \\
\text { c. Chemical }\end{array}$ & Interrater & $\begin{array}{l}\text { Predictive } \\
\text { Concurrent }\end{array}$ & $\mathrm{PA} / \mathrm{HE}$ \\
\hline
\end{tabular}

Abbreviations: $\mathrm{HE}$, healthy eating; NA, not applicable; NR, not reported; PA, physical activity. 
(continued)

Table 2. Worksite Questionnaire Details, Review of Measures of Worksite Environmental and Policy Supports for Physical Activity and Healthy Eating, United States, 1991-2013

\begin{tabular}{|c|c|c|c|c|c|c|c|}
\hline Survey Name & $\begin{array}{l}\text { Administration } \\
\text { Mode }\end{array}$ & Year & $\begin{array}{c}\text { Survey Details } \\
\text { (No. of Items, } \\
\text { Time } \\
\text { Required) }\end{array}$ & $\begin{array}{l}\text { Sample (a. Sample } \\
\text { Size, b. Location, c. } \\
\text { Type of Worksite) }\end{array}$ & Reliability & Validity & $\begin{array}{l}\text { Health } \\
\text { Topic }\end{array}$ \\
\hline $\begin{array}{l}\text { Workplace } \\
\text { Walkability Audit } \\
\text { Tool (WWAT) (30) }\end{array}$ & Observational & 2005 & $14, N R$ & $\begin{array}{l}\text { a. } 10 \text { University } \\
\text { campuses } \\
\text { b. NA } \\
\text { c. Higher education }\end{array}$ & Interrater & NR & PA \\
\hline $\begin{array}{l}\text { Neighborhood } \\
\text { Quality of Life } \\
\text { Survey (NQLS) (31) }\end{array}$ & Self-report & 2004 & $32, N R$ & $\begin{array}{l}\text { a. } 1,313 \text { Working } \\
\text { adults } \\
\text { b. Seattle, Baltimore, } \\
\text { DC regions } \\
\text { c. Not reported }\end{array}$ & $\begin{array}{l}\text { Internal } \\
\text { consistency }\end{array}$ & NR & PA \\
\hline $\begin{array}{l}\text { Workplace Physical } \\
\text { Activity Framework } \\
\text { (WPAF) (32) }\end{array}$ & Manager report & 2003 & $45,30 \mathrm{~min}$ & $\begin{array}{l}\text { a. } 15 \text { Employees } \\
\text { b. Alberta, Canada } \\
\text { c. Education, } \\
\text { municipality, hospital }\end{array}$ & Interrater & Content & PA \\
\hline $\begin{array}{l}\text { Checklist of Health } \\
\text { Promotion } \\
\text { Environments at } \\
\text { Worksites (CHEW) } \\
(34)\end{array}$ & Multiple & 1995 & $112,>30 \mathrm{~min}$ & $\begin{array}{l}\text { a. } 20 \text { Worksites } \\
\text { b. Australia } \\
\text { c. Variety }\end{array}$ & Interrater & NR & $\mathrm{PA} / \mathrm{HE}$ \\
\hline $\begin{array}{l}\text { Heart Check } \\
\text { (HRTCHK) (35) }\end{array}$ & Manager report & 1993 & $226,>30 \mathrm{~min}$ & $\begin{array}{l}\text { a. }>10,000 \text { Employees } \\
\text { b. New York } \\
\text { c. Variety }\end{array}$ & $\begin{array}{l}\text { Interrater } \\
\text { internal } \\
\text { consistency }\end{array}$ & $\begin{array}{l}\text { Content } \\
\text { face } \\
\text { construct } \\
\text { criterion }\end{array}$ & $\mathrm{PA} / \mathrm{HE}$ \\
\hline
\end{tabular}

Abbreviations: HE, healthy eating; NA, not applicable; NR, not reported; PA, physical activity. 


\section{Appendix}

A. Supplemental figure. Breakdown of Worksite Instrument by Administration Mode, Review of Measures of Worksite Environmental and Policy Supports for Physical Activity and Healthy Eating, United States, 1991-2013. This file is available for download as a Microsoft Word document [DOCX - 19 KB].

B. Supplemental figure. Subdomain Coverage by Instrument, Review of Measures of Worksite Environmental and Policy Supports for Physical Activity and Healthy Eating, United States, 1991-2013. This file is available for download as a Microsoft Word document [DOC $-108 \mathrm{~KB}]$. 